\title{
Marxism Has the Theoretical Character of Keeping Pace with The Times
}

\author{
H.J. XING \\ Jilin Construction University, Changchun, Jilin, China
}

ABSTRACT: It's the continuous development of Marxism. Marxism itself is constantly in advance with The Times. As a Marxist truth, is the dialectical unification of absolute truth and relative truth. Keep pace with The Times is the essential attribute of Marxism, is the inevitable need of development of Marxism, is an eternal proposition of Marxism.

KEYWORD: Marxism; Keep pace with The Times; The theory of quality

Marx from produce to now has 150 years of history. Marx and Engels, according to the time of the social politics, economy and the development of the revolutionary situation, created the Marxism. Marxism is in their fight with all sorts of genres, constantly absorbing the excellent achievements of human culture gradually formed and developed. But both of Marx, Engels and Lenin, can ask them to answer the problem of hundreds and thousands of years. Other Marxists must according to the reality, understand, inherit and develop Marxism. Everything in the world is developing. Marxism is also developing and changing with the development of times. Therefore, from the development history of Marxism, it has the theoretical character of keeping pace with The Times.

Marxist development so far has experienced five periods:

\section{THE FIRST PERIOD: THE MARX DOCTRINE ESTABLISHMENT PERIOD}

From the middle of the 19th century to the end of the 19th century, namely from 1848 the birth of the communist manifesto to Engels died. This stage is the creation of Marxism. Marx and Engels is the founder of Marxism. They adapt to the needs of the proletarian revolutionary struggle, critically inherited the achievements of human thoughts and arduous theoretical. The birth of Marxism is a great invention in the history of human thought. In this period, Marx and Engels wrote many books, took part in many activities. Marx and Engels capitalism at that time were studied in the UK, France, Germany's development. In this period on the 19th century,
Marx and Engels wrote many books, took part in many activities. Half leaf of Europe, due to the development of productive forces, the capitalist mode of production internal contradictions increasingly intensified. The contradiction between the proletariat and the bourgeoisie became a principal contradiction of society. The proletariat boarded the stage of history as an independent political force, and is an urgent need to revolutionary theory to guide. Big advanced thoughts in the 19th century British classical political economics, classical German philosophy and French Utopian socialism provided ideological basis for the birth of Marxism. Marked by the declaration of the communist party in 1848, founded the Marxism. After that, Marx and Engels took part in the vigorous European revolution, both in theory and in practice constantly enrich and improve their theory and works. After defeat of the revolution in Europe in 1848 , to engage in the theory study of political economics, Marx volume I of "das capital" was published in 1867, Marx in the book deeply expounds the theory of surplus value, which reveals the nature of the capitalist economy and laws. Founded the Marxist political economics. Marx is very concerned about the Paris commune revolution action, failure at the Paris commune. Marx further summarizing the practical experience of the Paris commune revolution and great feats of the Paris commune gave high evaluation. Marxism from the creation that is under the premise of the stick to the truth, in constant correct mistakes, according to the practice to constantly enrich and develop theory, therefore said at the beginning of the founding of theoretical character of keeping pace with The Times. 


\section{THE SECOND PERIOD: THE MARX DOCTRINE INTO PRACTICE}

At the beginning of the 20th century in the 1920s, died during this period. Marx and Engels, Lenin inherited the great banner of Marxism, the theory of Marxism into practice, established the first socialist regime in the world.

In the era of Marx's life, the law of the unbalanced development of capitalism, had not give full play to the role. They according to the situation that socialism is possible in most advanced countries, by acting together to victory. Lenin according to the change of the new international situation, as well as the Russian political, economic, and social changes at that time, points out that socialism can't win at the same time in all countries, but it can be in one country or several countries to win. After that, the established international socialist countries, proves the correctness of the theory of Lenin. Should be clear that does not mean that Marxism is wrong, also does not mean negation of Marxism theory, Lenin but because great changes have taken place in the world, Marx and Engels just according to the situation of the conclusions, and Lenin is according to the development of The Times. The situation has changed and another conclusion, which fully indicates that the development of Marx is advancing with The Times. Lenin led the great "October revolution", the "October revolution" is the socialist revolution of the proletariat. It overthrew the bourgeois provisional government and stormed the bourgeois provisional government - the Winter Palace. Established in the history of the world's first of the proletariat in power of socialist country, the Soviet government of workers and peasants of the people's committee. The Russian October revolution broke through the imperialist front in the world, in $1 / 6$ of the world's land created the first socialist country. It not only motivates the struggle of the proletariat, and inspired the oppressed national liberation struggle. And shows the people all over the world a new seek liberation road. The victory of the October revolution promoted the spread of Marxism-Leninism in the world, proclaimed to the world a new social system by the ideal into reality. It is the first time in the history of mankind eliminate exploitation and oppression of social inequality, the first attempt to build common prosperity of fine social justice helped China's modern social revolution. It is the new development of Marxist theory, is a new model of Marxist theory keeping pace with The Times. This also proves that the Marxism is developed along with the development of The Times, it has the theoretical character of keeping pace with The Times

\section{THE THIRD PERIOD: THE INFINITE DEVELOPMENT PERIOD OF MARX THEORY}

From the 1920s and ' $60 \mathrm{~s}$. This period is the infinite of the development of Marxist theory. Socialist country by the original Soviet Union, a country to develop into Europe, Asia, America and many other countries, in history, has formed a socialist camp. After death of Lenin, Stalin as the main leaders of the Soviet party and the country to lead the people of the Soviet Union and hard struggle, through a series of sharp complex internal and external struggles, the difficulties of the service, the Soviet Union built the first socialist industrial powers. During this period, the people of the Soviet Union did not predecessors or it can draw lessons from the experience, completely according to what happened at the time, to find a way to solve practical problems. In the east, the communist party of Mao Zedong's leadership of the communist party of China and the Chinese people, not copying the Soviet city model, but according to the actual situation of China, put forward "in rural areas to encircle the cities, the armed seizure of power". Mao Zedong put the Marxism basic principle combined with China's actual, with dozens of years, made a historic contribution to Marxism, is the original Marxist theory of a major breakthrough has the theoretical character of keeping pace with The Times.

\section{THE FOURTH PERIOD: THE TORTUOUS DEVELOPMENT PERIOD OF MARX THEORY}

From the 1960s to the late 20th century. During this period, the socialist revolution has experienced a tortuous development process, at the same time, there has been a great innovation of Marxism. Twists and turns in this period mainly have two: One is the collapse of the Soviet Union; the other is eastern Europe upheaval. After the second world war, as the change of historical conditions, the Soviet Union in the thirties of the socialist mode has exposed many problems and shortcomings. For example, the one-sided emphasis on developing heavy industry, especially heavy industry, related to the military to ignore the development of light industry. Especially related to people's life, relatively backward production of life necessities of people's living standards without large increase, the Soviet party and state leaders of Marxist faith began to shake, especially after Gorbachev came to power, "humane and democratic socialism", not according to the world the development of the situation and the needs of the development of the socialist Soviet Union timely put forward suitable for the situation of reform ideas, but the one-sided emphasis on democracy and openness. Its core content is abstract 
humanism, is with a set of theoretical system of Marxist phase deviation, eventually lead to the failure of the reform of the Soviet Union, eastern European countries also lost the ruling status of communist party. The socialist countries also ceased to exist.

In China has experienced a decade of the "cultural revolution", which indicates that the development of Marxism is not plain sailing. It also has twists and turns the process of development and even retrogression. Comrade Deng Xiaoping timely, adhere to the "emancipate the mind, seeking truth from facts", adhere to the Marxist universal principles combined with China's concrete practice, creatively developed the Marxism.

\section{THE FIFTH PERIOD: EXPLORATION PERIOD OF MARX THEORY}

It's the end of the 20th century to the early $21 \mathrm{st}$ century, during this period, the Marxist theory, in the period of exploring the development of Marxism is the theory and practice, advancing with The Times, continuous innovation process.

During this period, with the communist party of China, and a firm Marxist, representative of, according to the needs of the development of China's actual and the combination of Marxist theory with China's concrete practice, creatively developed the Marxism. Comrade Jiang Zemin in new historical conditions, emphasizing the Marxist theoretical character of the most important is to keep pace with The Times. He will answer how to correctly understand the historical process of socialist development, how to know the process of the development of the capitalism, how to understand China's socialist reform practice process influence on people's thoughts. We must see the communist manifesto, published in more than one hundred and fifty years the world politics, economy, culture, science and technology development of major changes, consciously thinking and understanding from those malapropos ideas, practices and systems. From the fetters of subjectivism and metaphysics, good at unity thoughts in emancipating the mind, with the development of Marxism to guide the new practice.

During this period, Marxism advancing with The Times in China's performance is: combining Marxism with China's actual produced two leaps: the first is a historic leap of Marxism with the concrete practice of Chinese revolution and construction, is the theory achievements of Mao Zedong thought. The second is a historic leap of Marxism with the concrete practice of contemporary China's socialist modernization construction, is the theory achievements of Deng Xiaoping theory, also called the theory of socialism with Chinese characteristics. Mao Zedong in 1938, the first in the article titled "on the new stage" the problem of "Marxism" is proposed. Sinicization of Marxism in China has produced Mao Zedong thought, Deng Xiaoping theory and "three represents" important thought and the concept of scientific development theory. Application of the theory of Marxism, Chinese Communist Party led the Chinese people, has carried on the reform and opening up and socialist construction has made remarkable achievements, all these achievements, without revolutionary theory there can be no revolutionary practice, the history of Marxist theory, is the history of continuous innovation. The theory of Marxism in China is advancing with The Times development new look, Mao Zedong thought, Deng Xiaoping theory, which is formed by the "three represents" important thought and the concept of scientific development theory results, both in line, and their form the relatively independent system of new theory, is the history of Marxist development. In the contemporary, the Communist Party of China people only advancing with The Times, standing in the time front row, based on the new practice, grasp the new characteristics of The Times, with the basic theory of Marxism studies the major problems in reality, the deepening of communist rule, socialist construction law, the understanding of the law of development of human society, constantly absorb all new experience, new ideas and new achievements of science, to be able to enrich and develop Marxism new contribution. All this suggests that Marxism has the theoretical character of keeping pace with The Times From Marxism was founded to formation and tortuous development process. Marxism is the seed of development. It has the theoretical character of keeping pace with The Times. It has always been strictly based on objective facts. The reality is always constantly changing. The change of intense and deep nearly one hundred years to reach the level of the predecessors'. It's hard to imagine. Marxism must along with the development of era, practical and scientific and constantly changing.

\section{REFERENCES}

[1] Huang,W.D. April, 2002.Offering of the Soviet Communist Party Make Progress Its Decade. Jiangxi University Press.

[2] Duan, Z.Q. September, 1998. The History of Marxist Tutorial. Higher Education Press. 